Research Article

\title{
Compliance in taking medication for hypertension patients listed at Healthy Indonesia Program with a Family Approach
}

Merry Tiyas Anggraini ${ }^{1 *}$, Aisyah Lahdji ${ }^{2}$, Hema Dewi Anggraheny ${ }^{3}$

1) Departement of Family Medicine, Medical Faculty of Universitas Muhammadiyah Semarang

2) Departement of Public Health, Medical Faculty of Universitas Muhammadiyah Semarang

3) Departement of Public Helath, Medical Faculty of Universitas Muhammadiyah Semarang

\section{A R T I C L E I N F O}

\section{Submitted : $25^{\text {th }}$ August 2021 \\ Accepted : $26^{\text {th }}$ October 2021 \\ Published : 25 $5^{\text {th }}$ January 2022}

\section{Keywords:}

Education, Economic,Knowledge, Compliance

\section{*Correspondence:}

merry.tyas@unimus.ac.id

\section{This is an Open acces article} under the CC-BY license

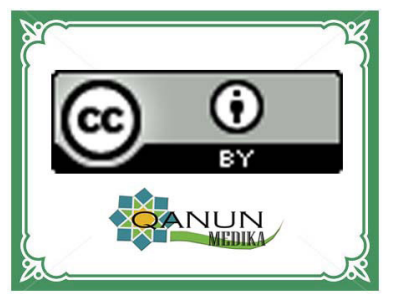

\section{ABSTRACT}

Compliance is the main factor in determining the success of treatment of hypertension and is needed for controlling the prevention of complications so that it is included in one of the Healthy Indonesia Program with a Family Approach (PIS-PK/Program Indonesia Sehat dengan Pendekatan Keluarga) indicators. This research aims to determine the relationship between education level, economic status, and knowledge level with compliance in taking medication. This research was observational analytic with a cross-sectional approach. The respondents in this study were hypertension patients listed on PIS-PK in the Mijen District for the period January-August 2020, which included the inclusion and exclusion criteria of 45 respondents. Primary data were obtained using MMAS-8, HK-LS, and a hypertension management knowledge questionnaire. Technique sampling was used consecutively. Data analysis used the Spearman rank correlation test. In this research can be concluded education level $(p=0.025)$ with relation coefficient $(\mathrm{r}=0.334)$ and economic status $(\mathrm{p}=0.000)$ with relation coefficient $(\mathrm{r}=0.550)$, level of knowledge about hypertension $(\mathrm{p}=0.000)$ with relation coefficient $(\mathrm{r}=$ $0.545)$ and knowledge about hypertension management $(p=0.005)$ with relation coefficient $(r=0.413)$. The higher level of education, the economic status, the level of knowledge its makes higher the compliance in taking medication for hypertension patients listed on the Healthy Indonesia Program with a Family Approach in the Mijen District. 


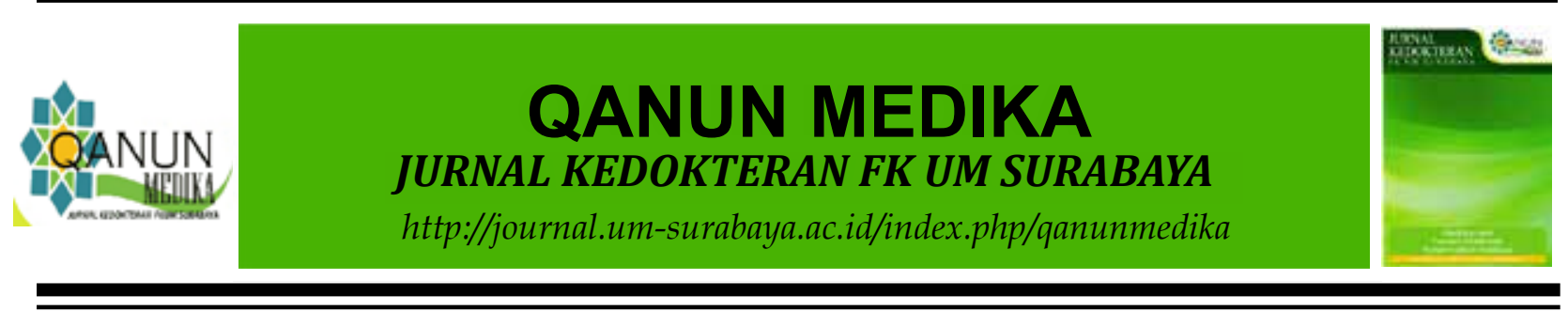

\section{INTRODUCTION}

Hypertension is an increase in systolic blood pressure $140 \mathrm{mmHg}$ and diastolic blood pressure $90 \mathrm{mmHg}$ in two measurements with an interval of five minutes in a state of sufficient rest/quiet (Unger T, Borghi C, Charchar F, 2020). Data and Information Center of the Indonesian Ministry of Health in 2019 presented data on Basic Health Research (Riskesdas) in 2018. The prevalence of hypertension in the population $>18$ years based on national measurements was $34.11 \%$. According to these data in terms of medication adherence, as many as $54 \%$ of hypertension patients regularly take medication, $32.27 \%$ of hypertensive patients do not routinely take medication, and $13.33 \%$ of hypertensive patients do not take medication at all (Kementrian Kesehatan RI., 2018).

Compliance in taking medication for hypertension patients is included in one of the indicators in the Healthy Indonesia Program with a Family Approach (PIS-PIK/ Program Indonesia Sehat dengan Pendekatan Keluarga). Healthy Family Index Data in 2019 nationally hypertension is $24.36 \%$ (Kementrian Kesehatan RI., 2020). In comparison, the Healthy Family Index data for hypertension in Central Java province is $21.04 \%$. In the city of Semarang, hypertension patients who take medication regularly are only $30.17 \%$. The lowest is in the Mijen sub-district of $15.01 \%$ with a healthy family index of only 0.35 , meaning that the family is not healthy (Permenkes No 39 Tahun 2016 Tentang Pedoman Penyelenggaraan Program Indonesia Sehat Dengan Pendekatan Keluarga., 2016). There are two health centers in Mijen District, namely Karangmalang Health Center and Mijen Health Center. The lowest Healthy Family Index Karangmalang health center is Wonoplumbon village 9.68\%. Meanwhile, the lowest Healthy Family Index
Mijen Public Health Center was Bubakan subdistrict 13.39\% (Kementrian Kesehatan RI., 2019).

Behavior can affect compliance. In Lawrence Green's Theory, behavior is influenced by predisposing factors, supporting factors, and reinforcing elements (Notoatmodjo, 2014). Knowledge is a predisposing factor that facilitates the occurrence of a behavior. If a person's knowledge is good, they will obey in taking treatment because that person desires to recover so that it encourages the formation of compliance behavior (Darker CD, 2011).

Knowledge in particular about hypertension and its management will significantly affect compliance in taking medication. Reinforced by previous research, there is a significant relationship between patients' knowledge of hypertension and adherence to taking medication (Aldano A. Limbong, Adisti Rumayar, 2018). Based on this concept, knowledge may be related to compliance in taking medication in patients with hypertension (Budi et al., 2016).

Compliance in taking medication in patients with hypertension is also influenced by several other factors such as the level of knowledge, motivation, support from health workers, family support, the influence of the number of drugs consumed, access to health services, employment status, education level, length of suffering, participation in health insurance, and economy (Puspita, 2016) (Pujiyanto, 2018).

In several previous studies, it was found that education was related to compliance in taking medication for hypertension patients. Still, some studies stated that education was not associated with compliance in taking medication for hypertension patients. The minimum number of studies that discuss the factors that influence adherence to taking hypertension medication makes researchers interested in conducting this study. 


\section{METHODS}

This study was approved by the Medical Faculty University Muhammadiyah Semarang ethical commission with the number 028/EC/FK/2021. This study used an observational analytic method with a cross-sectional approach. The study was conducted in the Mijen Public Health Center and Karangmalang Health Center in Mijen District from January to February 2021. 45 respondents met the inclusion and exclusion criteria using a consecutive sampling technique.

Inclusion criteria were all hypertensive patients that were listed at PIS-PK and treated for at least 1 month in the Mijen Health Center and Karangmalang Health Center, more than 18 years old, willing to become research respondents. Meanwhile, the exclusion criteria were hypertensive patients with mental, cognitive, and psychiatric disorders, hypertension patients with complications such as coronary heart disease, stroke, heart failure, and kidney disease.

The study used primary data from MMAS8 (Modifed Morisky Adherence Scale) questionnaire (Morisky DE, Ang A, Krousel WM, 2018) (Harijanto W, Rudijanto A, 2015), Hypertension Knowledge Level Scale (HKLS), hypertension management knowledge questionnaire that had passed the validity and reliability tests and direct interviews as well as secondary data obtained from the annual report of the puskesmas containing PIS-PK data for hypertension patients and medical record. The Spearman Rank correlation test analyzed data; $\mathrm{p}$-value $\leq 0.05$ means a relationship between the independent and dependent variables. (Dahlan, 2014) Interpretation of relationship level using correlation interpretation guidelines as follows:
1) $0.00-0.199$ : very low relationship
2) $0.20-0.399:$ low relationship
3) $0.40-0.599:$ moderate relationship
4) $0.60-0.799:$ strong relationship
5) $0.80-1,000$ : very strong relationship

\section{RESULTS}

Based on the table 1 above shows that the majority of the respondents are in the 46-55 year old group (31.1\%), female respondents (77.8\%), respondents with basic education level as many $(80.0 \%)$, respondents with low economic $(77.8 \%)$, respondents who know about low hypertension (75\%), respondents who know good hypertension management (65.9\%), and majority respondents have low compliance in taking medication levels (75\%).

Based on table 2 above shows low compliance to the question "Have you ever stopped taking medication or reduced the dose without telling your doctor because of the unpleasant effects of taking high blood pressure medication?" by $22.2 \%$. And high adherence to the question "Take medicine every day is really uncomfortable for some people, have you ever felt disturbed while taking your high blood pressure medication?" by $75.6 \%$.

Based on table 3, the results of the analysis of the correlation between education level and compliance in taking medication obtained a correlation coefficient of +0.334 which means that there is a low relationship with a positive distribution direction, namely increasing the level of education, the level of compliance in taking medication will also increase. The Spearman rank correlation test results in a p-value of 0.025 which means that there is a significant relationship between education level and compliance in taking medication. The analysis of the relationship between economic status and compliance in taking medication obtained a correlation coefficient of +0.550 which means that there is a moderate relationship with a positive distribution direction, namely increasing economic status, increasing the level of compliance taking medication. The Spearman rank correlation test results in the value of $p=0.000$, which means a significant relationship between education level and compliance in taking medication. 


\section{QANUN MEDIKA \\ JURNAL KEDOKTERAN FK UM SURABAYA \\ http://journal.um-surabaya.ac.id/index.php/qanunmedika}

Table 1. Univariate analysis based on age, gender, education level, level of knowledge about hypertension and hypertension management, economic status, and compliance in taking medication.




Table 2. Compliance Assessment Based on MMAS-8

\begin{tabular}{|c|c|c|c|}
\hline Description & $\begin{array}{l}\text { Yes } \\
(\%) \\
\end{array}$ & $\begin{array}{l}\text { No } \\
(\%)\end{array}$ & $\begin{array}{c}\text { Total } \\
(\%)\end{array}$ \\
\hline Do you sometimes forget to take medication? & 64.4 & 35.6 & 100.0 \\
\hline $\begin{array}{l}\text { Within } 2 \text { weeks. are there days that you dont } \\
\text { take medication not because you forgot? }\end{array}$ & 53.3 & 46.7 & 100.0 \\
\hline $\begin{array}{l}\text { Have you ever stopped taking medication or } \\
\text { reduced the dose without telling the doctor } \\
\text { because you felt bad effects when taking } \\
\text { medication? }\end{array}$ & 77.8 & 22.2 & 100.0 \\
\hline $\begin{array}{l}\text { When you travel or leave the house. do you } \\
\text { sometimes forget to bring your medication? }\end{array}$ & 28.9 & 71.1 & 100.0 \\
\hline Did you not take medication yesterday? & 55.6 & 44.4 & 100.0 \\
\hline $\begin{array}{l}\text { When you feel your blood pressure is under } \\
\text { control. do you sometimes stop taking } \\
\text { medication? }\end{array}$ & 66.7 & 33.3 & 100.0 \\
\hline $\begin{array}{l}\text { Taking medicine every day is really } \\
\text { uncomfortable for some people. have you ever } \\
\text { felt disturbed when taking your medication? }\end{array}$ & 24.4 & 75.6 & 100.0 \\
\hline $\begin{array}{l}\text { How often do you have trouble remembering to } \\
\text { take medication? }\end{array}$ & 51.1 & 48.9 & 100.0 \\
\hline
\end{tabular}

Table 3. Analysis Result Rank Spearman Test

\begin{tabular}{lcc}
\hline \multicolumn{1}{c}{ Variable } & $\mathbf{p}$ & $\mathbf{r}$ \\
\hline Economis status & 0.000 & 0.550 \\
Education Level & 0.025 & 0.334 \\
Level of knowledge about hypertension & 0.000 & 0.545 \\
$\begin{array}{l}\text { Level of knowledge about hypertension } \\
\text { management }\end{array}$ & 0.005 & 0.413 \\
\hline
\end{tabular}




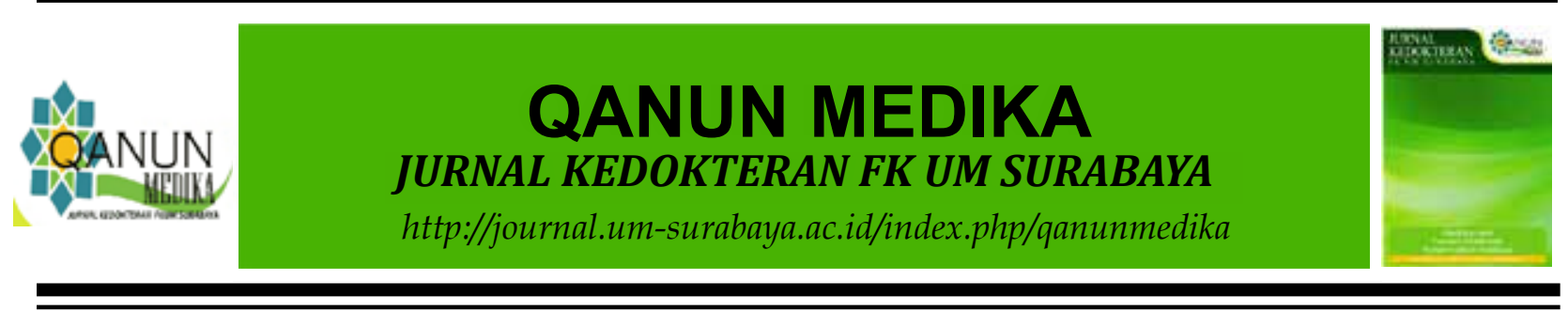

The results of the analysis of the correlation between the level of knowledge about hypertension and compliance in taking medication obtained a correlation coefficient of +0.545 which means that there is a low relationship with a positive distribution direction, namely increasing the level of knowledge about hypertension, the level of compliance in taking medication will also increase. The Spearman rank correlation test results in the value of $p=0.000$, which means that there is a significant relationship between the level of knowledge about hypertension and compliance in taking medication. The results of the analysis of the correlation between the level of knowledge about the management of hypertension and compliance to taking medication obtained a correlation coefficient of +0.413 which means that there is a moderate relationship with a positive distribution direction, namely increasing economic status, increasing the level of compliance in taking medication. The Spearman rank correlation test results in a p-value of 0.005 which mean that there is a significant relationship between the level of knowledge about hypertension management and compliance in taking medication.

\section{DISCUSSION}

Based on result, respondents who have compliance in taking medication.get a low score due to several points, namely, firstly, intentionally stopping taking medication without the doctor's knowledge, secondly stopping taking medication because they feel that their blood pressure is under control, thirdly the frequency of forgetting to take medicine, fourthly schedule. The previous day, the fifth within 2 weeks did not take medicine, the six patients had difficulty remembering to take the medication, the seventh was the availability of treatment while traveling, and the last one was due to the inconvenience of taking medicine every day.
Educational level was significantly related to compliance in taking medication in hypertension patients in Mijen District. According to the interview, respondents with a basic education tend to have low compliance scores because they think they take medication only when complaints of hypertension arise and when complaints subside, they tend to stop taking medication. Respondents with basic education levels also tend to often forget to take their medicine. Respondents with a middle education level tend to have moderate compliance scores because they feel disturbed by taking medication every day and think that taking medication every day will negatively impact the kidneys. Respondents with high education tend to have high compliance scores because they think that hypertension requires regularity in taking medication so that blood pressure is controlled to avoid complications. The results of this study are in sync with previous research; there is a significant relationship between the level of education and compliance in taking medication in patients with hypertension at the Kajen Regional General Hospital, Pekalongan Regency (Ahda, 2016). Education can influence health behavior because education makes a person more able to absorb and get news from health workers. The mindset is more developed, logical and considers various considerations to maintain or overcome health problems (Notoatmodjo, 2011). The increase in education history will increase compliance to taking medication (Notoatmodjo, 2010).

According to this study, it was found that the economic status of the respondents was significantly affiliated with compliance in taking medication in hypertension patients in Mijen District. Based on the interviews, respondents with low economic status have low compliance scores because they are less able to meet their daily needs, so they choose not to visit the puskesmas to take medicine regularly. Hypertension patients get free medicine 
through programs at the Puskesmas, but they have difficulty taking medication because of the high transportation costs to reach the puskesmas. Respondents with high economic status have moderate to high compliance scores because they can meet their daily needs. So respondents with the high financial situation do not take medication at the health center. They will check with private practice doctors or buy drugs at pharmacies independently. The results of this study are in sync with previous research, namely, the level of income is one of the socioeconomic factors affecting hypertension patients in compliance to taking medication (Pujiyanto, 2018) (Rasajati QP, Raharjo BR, 2015).

Economic status can affect health behavior because income affects health consumers and health services to control problems related to health (Notoatmodjo, 2011). As financial status increases, compliance to medication also increases (Notoatmodjo, 2010).

This study found that knowledge about hypertension and its management had a significant relationship with compliance in taking medication. Based on the results of the answers to the questionnaire, most respondents did not know about medical treatment and complications related to hypertension. The majority of respondents do not take medicine every day but only take medicine when they feel sick. The majority do not know that hypertension will cause advanced diseases such as visual disturbances and kidney and heart disease if not treated immediately.

Based on the results of this study, the majority of respondents did not routinely check their blood pressure at the puskesmas; respondents usually visit the puskesmas when they feel unbearable symptoms. If the patient does not feel the symptoms of hypertension such as dizziness and the neck feels heavy, they think their blood pressure has returned to normal, and then they do not take medication. So that the lack of knowledge about hypertension and its management causes respondents not to have the self-awareness to change lifestyle behavior towards a healthier direction and do not understand the importance of taking medication every day. The theory states that a fundamental domain in shaping one's actions is knowledge. If it is based on the understanding of the behavior, it will be lasting (Notoatmodjo, 2014). In line with previous research, knowledge in patients with high blood pressure can affect regularity in taking medication (Ikhwan M, Livana PH, 2017) (Haldi T, Pristianty L, 2021).

The benefit of this research is that it can add reference material for improving service policies in Healthy Indonesia Program with a Family Approach. The limitation of this research is that it used a cross-sectional method, so that it is difficult to assess cause and effect because data collection is carried out at the same time.

\section{CONCLUSION}

According to the analysis and discussion results, it can be concluded that the increase in education level, level of knowledge about hypertension and its management, and economic status will increase the level of compliance to taking medication.

\section{REFERENCES}

Ahda, M. H. (2016). Pengaruh tingkat pendidikan dan dukungan keluarga terhadap tingkat kepatuhan minum obat pada pasien hipertensi di Rumah Sakit Umum Daerah Kajen Kabupaten Pekalongan tahun 2016 [University of MUhammadiyah Semarang (UNIMUS)]. http://repository.unimus.ac.id/id/ eprint $/ 208$

Aldano A. Limbong, Adisti Rumayar, G. D. K. (2018). Hubungan pengetahuan dan sikap 


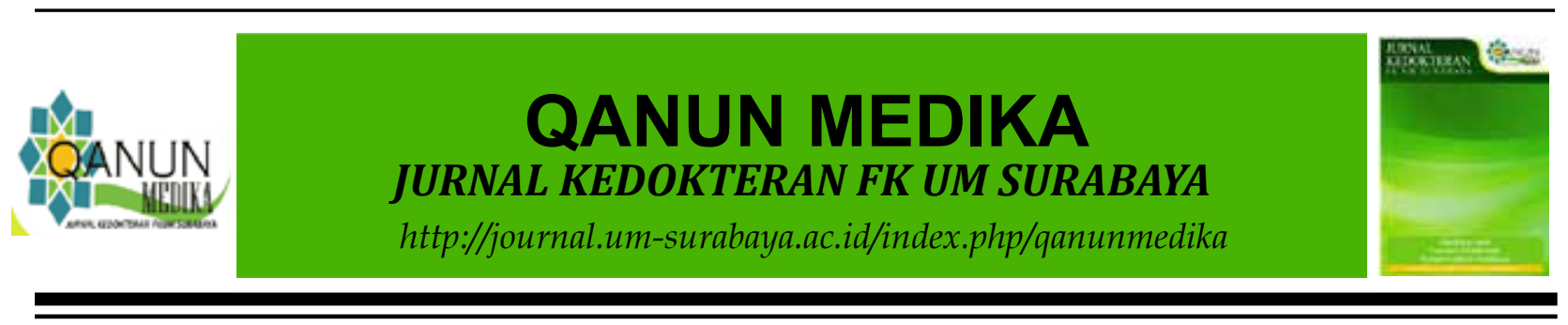

dengan kejadian hipertensi di wilayah puskesmas Tateli Kabupaten Minahasa. Jurnal Kesmas, 7(4). https://ejournal. unsrat.ac.id/index.php/kesmas/article/ view/23122

Budi, S., Wiedyaningsih, C., \& Widodo, G. P. (2016). Pengaruh Tingkat Pengetahuan Terhadap Kualitas Hidup Dengan Kepatuhan Penggunaan Obat Sebagai Variabel Antara Pada Pasien Hipertensi di Depo Farmasi Rawat Jalan RS PKU Muhammadiyah Surakarta [Universitas Setia Budi]. https://www. academia.edu/32261220/PENGARUH_ TINGKAT_PENGETAHUAN TER H A D P _ K U L I T A S HIDUP_DENGAN_KEPATUHAN_ PENGGUNAAN_OBAT_SEBAGAI_ VARIABEL_ANTAR_PADA_ PASIEN_A S M A_DI_DEPO_ FARMASIRAWAT_JALAN_RS_PKU_ MUHAMMADIYAH_SURAKARTA

Dahlan, M. S. (2014). Statistik untuk kedokteran dan kesehatan (6th ed.). Salemba Medika.

Darker CD, et al. (2011). An intervention to promote walking amongst the general population based on an "extended" theory of planned behaviour: a waiting list randomised controlled trial. Psychology \& Health, 25(Jan), 71-88. https://doi. org/10.1080/08870440902893716

Haldi T, Pristianty L, H. I. (2021). Hubungan pengetahuan dan sikap dengan kepatuhan minum obat amlodipine di puskesmas arjuno Kota Malang. Jurnal Farmasi Komunitas, 8(1), 27-31. https://doi. org/http://dx.doi.org/10.20473/jfk. v8i1.22277

Harijanto W, Rudijanto A, A. A. (2015). Pengaruh konseling motivational interviewing terhadap kepatuhan minum obat penderita hipertensi. Jurnal
Kedokteran Brawijaya., 28(4), 354-353. https://doi.org/http://dx.doi.org/10.21776/ ub.jkb.2015.028.04.16

Ikhwan M, Livana PH, H. (2017). Hubungan faktor pemicu hipertensi dengan kejadian hipertensi. Jurnal Kesehatan, 10(2), 1-11. https://doi.org/https://doi.org/10.32763/ juke.v10i2.40

Permenkes No 39 tahun 2016 Tentang Pedoman Penyelenggaraan Program Indonesia Sehat dengan Pendekatan Keluarga., Pub. L. No. 39 (2016). https://peraturan.bpk. go.id/Home/Details/113087/permenkesno-39-tahun-2016

Kementrian Kesehatan RI. (2018). Hipertensi Si Pembunuh Senyap. Infodatin Pusat Data Dan Informasi Kementrian Kesehatan Republik Indonesia. https://pusdatin. kemkes.go.id/resources/download/ pusdatin/infodatin/infodatin- hipertensisi-pembunuh-senyap.pdf

Kementrian Kesehatan RI. (2019). Rekapitulasi indeks keluarga sehat per provinsi di Indonesia tahun 2019.

Kementrian Kesehatan RI. (2020). Rekapitulasi IKS. http://dashboard-keluargasehat. kemkes.go.id/

Morisky DE, Ang A, Krousel WM, W. H. (2018). Predictive validity of a medication adherence measure in an outpatient setting. Journal Clinical Hypertension, 10(5), 348-354. https://doi.org/https://doi. org/10.1111/j.1751-7176.2008.07572.x

Notoatmodjo, S. (2010). Pendidikan dan perilaku kesehatan. Rineka Cipta.

Notoatmodjo, S. (2011). Kesehatan masyarakat ilmu dan seni (revisi 201). Rineka Cipta.

Notoatmodjo, S. (2014). Ilmu perilaku kesehatan. Rineka Cipta.

Pujiyanto, P. (2018). Faktor sosio ekonomi yang mempengaruhi kepatuhan minum 


\section{QANUN MEDIKA \\ JURNAL KEDOKTERAN FK UM SURABAYA \\ http://journal.um-surabaya.ac.id/index.php/qanunmedika}

obat antihipertensi. Jurnal Kesehatan Masyarakat Nasional National Public Health Journal, 3(3). https://doi.org/http:// dx.doi.org/10.21109/kesmas.v3i3.228

Puspita, E. (2016). Faktor-faktor yang berhubungan dengan kepatuhan penderita hipertensi dalam menjalani pengobatan [Universitas Negeri Semarang]. http://lib. unnes.ac.id/23134/

Rasajati QP, Raharjo BR, N. D. (2015). Faktor-faktor yang berhubungan dengan kepatuhan pengobatan pada penderita hipertensi di wilayah kerja Puskesmas Kedungmundu Kota Semarang. Unnes
Jurnal of Public Health, 4(3), 256-63. https://doi.org/https://doi.org/10.15294/ ujph.v4i3.6339

Unger T, Borghi C, Charchar F, et al. (2020). International society of hypertension practice guideline. American Heart Association. American Heart Association, 75(6). https:// doi.org/https://doi.org/10.1161/ HYPERTENSIONAHA.120.15026 